\title{
FAKTOR-FAKTOR YANG MENJADI PENYEBAB KENAKALAN REMAJA
}

\author{
Oleh: \\ Dr. Azwar Agus, SH, M.Hum \\ (Dosen Tetap FH Universitas Tamansiswa Palembang)
}

\begin{abstract}
ABSTRAK
Laporan "United Nations Congress on the Prevention of Crime and the Treatment of Offenders" yang bertemu di London pada tahun 1960 menyatakan adanya kenaikan jumlah juvenile delinquency (kejahatan anak remaja) dalam kualitas kejahatan, dan peningkatan dalam kegarangan serta kebengisannya yang lebih banyak dilakukan dalam aksi-aksi kelompok daripada tindak kejahatan individual. Penyebab kenakalan remaja sangat kompleks. Semua pihak ikut berkontribusi terhadap munculnya kenakalan remaja, baik secara aktif maupun pasif
\end{abstract}

\section{A. Latar Belakang}

Masa remaja adalah masa penuh warna dan dinamika, disertai rangkaian gejolak emosi yang menghiasi perjalanan seorang manusia yang hendak bertumbuh dewasa. Bagi remaja, di masa inilah mereka mulai mengenal lingkungan luar. Sudah cukup masa kecil yang hanya berada di seputar lingkungan keluarga atau temanteman dekat saja. Para remaja akan cenderung semakin memperluas lingkungan pergaulannya, baik berinteraksi secara langsung ataupun dengan perantara teknologi (seperti internet atau telpon genggam).

Pada masa remajalah seorang manusia mulai membangun jati diri, memiliki kehendak bebas, memegang teguh prinsip, dan mengembangkan kapasitasnya. Di masa ini pula, ia rentan terkena pengaruh dari pergaulan dengan teman-temannya. Karena kehendak bebas yang mereka miliki serta dorongan pergaulan yang semakin dinamis, menyebabkan remaja cenderung mudah mengikuti pengaruh lingkungan sekitarnya. Jika lingkungan tempat mereka bergaul itu positif, maka mereka akan semakin berkembang kearah positif. Tapi, jika mereka terjerumus dalam lingkungan negatif, maka remaja juga akan terdorong melakukan hal-hal negatif. 
Remaja adalah fondasi masyarakat. Kalau mereka baik, baik pulalah masyarakat. Kalau mereka rusak, rusak pulalah masyarakat. ${ }^{1}$

Laporan "United Nations Congress on the Prevention of Crime and the Treatment of Offenders" yang bertemu di London pada tahun 1960 menyatakan adanya kenaikan jumlah juvenile delinquency (kejahatan anak remaja) dalam kualitas kejahatan, dan peningkatan dalam kegarangan serta kebengisannya yang lebih banyak dilakukan dalam aksi-aksi kelompok daripada tindak kejahatan individual. ${ }^{2}$

Fakta kemudian menunjukkan bahwa tipe kejahatan remaja itu semakin bertambah jumlahnya dengan semakin lajunya perkembangan industrialisasi dan urbanisasi. Di kotakota industri dan kota besar yang cepat berkembang secara fisik, terjadi kasus kejahatan yang jauh lebih banyak daripada masyarakat "primitive" atau di desa-desa. Dan di negaranegara kelas ekonomi makmur, derajat kejahatan ini berkorelasi akrab dengan proses industrialisasi. Karena itu Amerika sebagai negara paling maju secara ekonomis di antara bangsa-bangsa di dunia, mempunyai jumlah kejahatan anak remaja paling banyak; jadi ada derajat kriminalitas anak remaja paling tinggi.

Dalam tulisani ini penulis akan membahas permasalahan sebagai berikut : faktor-faktor apakah yang menyebabkan terjadinya kenakalan remaja?

\section{B. Tinjauan Pustaka}

Remaja adalah fase peralihan antara masa kanak-kanak dan masa tumbuh dewasa, baik secara fisik, akal, kejiwaan, sosial, dan emosional. Pandangan ini diperkuat oleh teori Piaget, "Secara psikologis, masa remaja adalah usia saat individu berintegrasi dengan masyarakat dewasa, usia saat anak tidak merasa di bawah tingkat orang-orang yang lebih tua, melainkan berada dalam tingkatan yang sama, sekurangkurangnya dalam masalah hak. Transformasi intelektual yang khas dari cara berpikir remaja ini memungkinkannya untuk mencapai integrasi dalam hubungan sosial dengan orang dewasa, yang kenyataannya merupakan cirri khas yang umum dari periode perkembangan ini. ${ }^{3}$

\footnotetext{
${ }^{1}$ Muhammad Ahmad Kan'an, Potret Buram Dunia Remaja (Siapa Peduli?), Intermedia, Solo, 2003, hlm. 102

${ }^{2}$ Kartini Kartono, Kenakalan Remaja, Rajawali Pers, Jakarta, 2006, hlm. 3

${ }^{3}$ Muhammad Al-Mighwar, Psikologi Remaja, Petunjuk bagi Guru dan Orang Tua, Pustaka Setia, Bandung, 2006, hlm. 55-56
} 
Pada fase ini, tubuh anak mengalami perubahan dan peralihan penting, baik dari sisi berat, ukuran, maupun bentuknya. Perubahan juga berlangsung di bagian dalam, yakni sisi emosi dan kejiwaan. Perubahan tubuh berjalan secara cepat dan berkelanjutan, yang ditandai dengan tinggi badan, kekuatan, dan bobot yang semakin bertambah. Anak laki-laki terlihat lebih tinggi dan otot-ototnya lebih kentara. ${ }^{4}$

Menurut Prof. Drs Agoes Soejanto, masa remaja terentang antara usia 13 sampai 22 tahun. Masa ini sangat menentukan hari depan dan kehidupan seorang remaja sehingga seharusnya dipersiapkan dan dijalani dengan sebaik-baiknya. Masa ini memang penuh dengan ujian dan tantangan, masa yang sukar dimengerti tapi harus dipahami, masa bergelora yang harus diselami baik oleh remaja dan siapa saja yang berkepentingan dengannya. ${ }^{5}$

Kata remaja (adolescent) berasal dari bahasa Latin alescere yang berarti tumbuh atau tumbuh menjadi dewasa. Istilah adolescent mempunyai arti yang lebih luas lagi, yakni mencakup kematangan, mental, emosional sosial, dan fisik. Pada masa ini, golongan remaja sebenarnya tidak mempunyai tempat yang jelas, karena mereka sudah tidak termasuk golongan anak tetapi juga belum masuk pada golongan dewasa atau tua. ${ }^{6}$

Kenakalan anak atau remaja diambil dari istilah Juvenile Delinquency. Juvenile artinya young, anak-anak, anak muda, cirri karakteristik pada masa muda sifat-sifat khas pada periode remaja, sedangkan Delinquency artinya doing wrong, terabaikan/mengabaikan, yang kemudian diperluas artinya menjadi jahat, a-sosial, criminal, pelanggar aturan, pembuat rebut, pengacau, penteror, tridak dapat diperbaiki lagi, durjana, dursila, dan lain-lain. ${ }^{7}$

\section{Pembahasan}

Penyebab kenakalan remaja sangat kompleks. Semua pihak ikut berkontribusi terhadap munculnya kenakalan remaja, baik secara aktif maupun pasif. Menurut

${ }^{4}$ Hassan Syamsi Basya, Mendidik Anak Zaman Kita: Cara Nabi dan Psikolog Muslim Mengantar Anak Lebih Cerdas, Lebih Saleh, Zaman, Jakarta, 2011, hlm. 275-276

${ }^{5}$ Agoes Soejanto, Psikologi Perkembangan, Rineka Cipta, Jakarta, 2005, hlm. 159-162

6 Jamal Ma'mur Asmani, Kiat Mengatasi Kenakalan Remaja di Sekolah, Buku Biru, Yogyakarta, 2012, hlm. 40

${ }^{7}$ Wagiati Soetodjo, Hukum Pidana Anak, Refika Aditama, Bandung,, 2006, hlm. 8-9 
Hassan Syamsi Basya, berbagai kajian mutakhir menunjukkan bahwa kenakalan remaja sebagian besar disebabkan penderitaan dan perlakuan buruk yang mereka alami pada masa kecil. ${ }^{8}$

Menurut penulis, ada beberapa faktor yang menyebabkan terjadinya kenakalan remaja, antara lain: (a) faktor lingkungan keluarga, (b) faktor lingkungan masyarakat, (c) faktor lingkungan sekolah, dan (4) pengaruh teknologi informasi.

1. Faktor Lingkungan Keluarga.

Keluarga merupakan lingkungan yang terdekat untuk membesarkan, mendewasakan dan di dalamnya anak mendapatkan pendidikan yang pertama kali. Keluarga merupakan kelompok masyarakat terkecil, akan tetapi merupakan lingkungan paling kuat dalam membesarkan anak dan terutama bagi anak yang belum sekolah. Oleh karena itu keluarga memiliki peranan yang penting dalam perkembangan anak, keluarga yang baik akan berpengaruh positif bagi perkembangan anak, sedangkan keluarga yang jelek akan berpengaruh negatif. Oleh karena sejak kecil anak dibesarkan oleh keluarga dan untuk seterusnya, sebagian besar waktunya adalah di dalam keluarga maka sepantasnya kalau kemungkinan timbulnya delinquency itu sebagian besar juga berasal dari keluarga. ${ }^{9}$

Adapun keadaan keluarga yang dapat menjadi sebab timbulnya delinquency dapat berupa keluarga yang tidak normal (broken home), keadaan jumlah anggota keluarga yang kurang menguntungkan.

a. Broken Home dan Quasi Broken Home.

Menurut pendapat umum pada broken home ada kemungkinan besar bagi terjadinya kenakalan remaja, di mana terutama perceraian atau perpisahan orang tua mempengaruhi perkembangan si anak.

Dalam broken home pada prinsipnya struktur keluarga tersebut sudah tidak lengkap lagi yang disebabkan adanya hal-hal:

1) Salah satu kedua orang tua atau kedua-duanya meninggal dunia.

2) Perceraian orang tua.

3) Salah satu kedua orang tua atau keduanya "tidak hadir" secara kontinyu dalam tenggang waktu yang cukup lama.

\footnotetext{
${ }^{8}$ Hassan Syamsi Basya, Op.Cit, hlm. 217

${ }^{9}$ Sudarsono, Kenakalan Remaja, Rineka Cipta, Jakarta, 1995, hlm. 125
} 
Keadaan keluarga yang tidak normal bukan hanya terjadi pada broken home, akan tetapi dalam masyarakat modern sering pula terjadi suatu gejala adanya "broken homosemu" (quasi broken home) ialah kedua orang tuanya masih utuh, tetapi karena masing-masing anggota keluarga (ayah dan ibu) mempunyai kesibukan masing-masing sehingga orang tua tidak sempat memberikan perhatiannya terhadap pendidikan anakanaknya. Dalam kaitan ini Bimo Walgito menjabarkan lebih jelas lagi bahwa: Tidak jarang orang tua tidak dapat bertemu dengan anak-anaknya. Coba bayangkan orang tua kembali dari kerja, anak-anak sudah bermain di luar, anak pulang orang tua sudah pergi lagi; orang tua datang anak-anak sudah tidur, dan seterusnya. Keadaan yang semacam ini jelas tidak menguntungkan perkembangan anak. Dalam situasi keluarga yang demikian anak mudah mengalami frustasi, mengalami konflik-konflik psikologis, sehingga keadaan ini juga dapat mudah mendorong anak menjadi delinkuen. ${ }^{10}$

Baik broken home maupun quasi broken home dapat menimbulkan ketidakharmonisan dalam keluarga atau disintegrasi sehingga keadaan tersebut memberikan pengaruh yang kurang menguntungkan terhadap perkembangan anak. Sedangkan dalam kenyataan menunjukkan bahwa anak-anak remaja yang melakukan kejahatan disebabkan karena di dalam keluarga terjadi disintegrasi.

b. Keadaan Jumlah Anak yang Kurang Menguntungkan

Aspek lain di dalam keluarga yang dapat menimbulkan anak remaja menjadi delinkuen adalah jumlah anggota keluarga (anak) serta kedudukannya yang dapat mempengaruhi perkembangan jiwa anak.

Di dalam rumah tangga dengan jumlah anggota warga yang begitu besar karena jumlah anak banyak, biasanya mereka kurang pengawasan dari kedua orang tua. Sering terjadi di dalam masyarakat kehidupan keluarga besar kadang-kadang disertai dengan tekanan ekonomi yang agak berat, akibatnya banyak sekali keinginan anak-anak yang tidak terpenuhi. Akhirnya mereka mencari jalan pintas yakni mencuri, menipu, dan memeras. Ada kemungkinan lain, dalam keluarga besar dengan jumlah anak yang banyak biasanya pemberian kasih saying dan perhatian dari kedua orang tua sama sekali tidak sama. Akibatnya, di dalam intern keluarga timbul persaingan dan rasa iri hati satu sama lain yang pada dasarnya akan mempengaruhi perkembangan jiwa anak.

2. Faktor Lingkungan Masyarakat

${ }^{10}$ Bimo Walgito, Kenakalan Anak (Juvenile Delinquency), Yayasan Penerbit Fak Psikologi UGM, Yogyakarta, 1982, hlm. 11 
Kartini Kartono,berpendapat bahwa: milie atau lingkungan sekitar tidak selalu baik dan menguntungkan bagi pendidikan dan perkembangan anak. Lingkungan adakalanya dihuni oleh orang dewasa serta anak-anak muda criminal dan anti sosial, yang bisa merangsang timbulnya reaksi emosional buruk bagi anak-anak puber dan adolesen yang masih labil jiwanya. Dengan begitu anak-anak remaja ini mudah terjangkit oleh pola kriminal, asosial dan asusila tadi.

Anak remaja sebagai anggota masyarakat selalu mendapat pengaruh dari keadaan masyarakat dan lingkungannya baik langsung maupun tidak langsung. Pengaruh yang dominan adalah ekselerasi perubahan sosial yang ditandai dengan peristiwa-peristiwa yang sering menimbulkan ketegangan seperti persaingan dalam perekonomian, pengangguran, mass media, dan fasilitas rekreasi.

\section{Faktor Lingkungan Sekolah}

Sekolah merupakan pendidikan formal, oleh karena itu sekolah besar sekali pengaruhnya terhadap perkembangan jiwa seorang anak. Kondisi sekolah, keadaan guru dan sistem pengajaran yang tidak menguntungkan menyebabkan anak cepat bosan, sehingga lingkungan sekolah itu tidak menarik perhatiannya.

Untuk menyalurkan rasa tidak puasnya itu mereka meninggalkan sekolah atau membolos, kesempatan ini mereka gunakan untuk menggabungkan diri dengan anakanak yang tidak sekolah.

Bismar Siregar, berpendapat, lingkungan sekolah adalah lingkungan pendidikan yang formal, sistem pelajaran dan kondisi sekolah yang tidak menguntungkan anak mungkin akan menjurus kepada kebosanan. Guru yang tidak simpatik, galak, tidak menyampaikan pelajaran, dan lainnya bisa juga membosankan murid. Mereka merasa bosan dan tidak mendapatkan kepuasan sehingga tidak segan-segan meninggalkan sekolah, serta membolos pada jam-jam pelajaran. Kesempatan ini mereka gunakan untuk keluyuran di jalan-jalan, bergabung dengan anak-anak lain. Waktu luang karena kekosongan guru yang tidak masuk, berarti kesempatan anak-anak untuk mencari kegiatan di luar lingkungan sekolah. Inilah yang terjadi di kota-kota besar seperti Jakarta. Manifestasinya bisa bermacam-macam, perkelahian, narkotik, melawan guru, dan lain sebagainya. ${ }^{11}$

Jadi ada beberapa faktor penyebab lingkungan tidak sehat, antara lain:

${ }^{11}$ Bismar Siegar, "Hanya Agama yang Mampu Mengatasi Perkelahian”, Majalah Suara Masjid No. 172, Januari 1989, hlm. 24 
a. Fasilitas sekolah, berupa gedung bangunan sekolah yang tidak memenuhi persyaratan;

b. Sarana pendidikan, seperti buku, alat-alat peraga masih terbatas jumlahnya,

c. Guru yang kurang dedikasi dan kurang memahami didaktik/metodik mengajar sehingga di dalam melaksanakan tugasnya asal saja.

d. Kewibawaan guru menurun, akibat perbedaan stratifikasi sosial.

e. Kurangnya kegiatan ekstra kurikuler di sekolah, sehingga anak merasa bosan dengan kegiatan yang sifatnya rutin. ${ }^{12}$

\section{Faktor Pengaruh Teknologi Informasi.}

Salah satu produk paling nyata dari perkembangan teknologi dunia modern adalah internet. Sebagaimana telepon genggam yang kini sudah menjadi barang kebutuhan utama, internet diperkirakan juga akan mengambil peranan yang semakin besar di masa depan. Keberadaan internet telah menjadikan dunia ini sebagai desa kecil yang melampaui batas-batas jarak dan waktu. Aneka peristiwa, gagasan dan temuan baru di berbagai bidang, kini dapat diakses secara lebih mudah, cepat dan murah.

Sayangnya, internet juga membawa dampak-dampak negatif di samping peranperan positifnya. Salah satunya, internet menjadi salah satu media utama yang mendorong timbulnya kenakalan remaja. ${ }^{13}$

Perkembangan media teknologi yang satu ini seringkali dikaitkan secara erat dengan penyebaran materi pornografi dan pornoaksi. Cukup dengan mendatango warnet terdekat, setiap remaja bisa mengakses hampir semua informasi yang ingin ia ketahui, termasuk informasi tentang seks. Karena banyak materi di internet dibuat secara global, bukan tidak mungkin situs-situs di dalamnya tidak melalui penyaringan atau sensor.

\section{Simpulan}

Dari pembahasan yang telah diuraikan diatas dapat ditarik kesimpulan sebagai berikut : faktor-faktor penyebab terjadinya kenakalan remaja antara lain adalah kondisi rumah tangga yang broken home, kurangnya perhatian orang tua, pengaruh pergaulan dalam masyarakat, kurangnya pengawasan dari sekolah, kurangnya kegiatan ekstra

\footnotetext{
${ }^{12}$ Moch Lukman Fatahullah, Tindak Pidana Perkelahian Pelajar, Sinar Harapan, Jakarta, 1997, hlm. 66

13 Jamal Ma'mur Asmani, Op. Cit, hlm. 133
} 
kurikuler di sekolah, sehingga anak merasa bosan dengan kegiatan yang sifatnya rutin dan adanya pengaruh perkembangan teknologi informasi.

\section{DAFTAR PUSTAKA}

Agoes Soejanto, Psikologi Perkembangan, Rineka Cipta, Jakarta, 2005

Bimo Walgito, Kenakalan Anak (Juvenile Delinquency), Yayasan Penerbit Fak Psikologi UGM, Yogyakarta, 1982.

Bismar Siegar, "Hanya Agama yang Mampu Mengatasi Perkelahian”, Majalah Suara Masjid No. 172, Januari 1989.

Hassan Syamsi Basya, Mendidik Anak Zaman Kita: Cara Nabi dan Psikolog Muslim Mengantar Anak Lebih Cerdas, Lebih Saleh, Zaman, Jakarta, 2011

Jamal Ma'mur Asmani, Kiat Mengatasi Kenakalan Remaja di Sekolah, Buku Biru, Yogyakarta, 2012.

Kartini Kartono, Kenakalan Remaja, Rajawali Pers, Jakarta, 2006

Moch Lukman Fatahullah, Tindak Pidana Perkelahian Pelajar, Sinar Harapan, Jakarta, 1997

Muhammad Al-Mighwar, Psikologi Remaja, Petunjuk bagi Guru dan Orang Tua, Pustaka Setia, Bandung, 2006.

Muhammad Ahmad Kan'an, Potret Buram Dunia Remaja (Siapa Peduli?), Intermedia, Solo, 2003,

Sudarsono, Kenakalan Remaja, Rineka Cipta, Jakarta, 1995.

Wagiati Soetodjo, Hukum Pidana Anak, Refika Aditama, Bandung, 2006 